\title{
The Cost of Pride:
}

\section{Why Do Firms from Developing Countries Bid Higher?}

\author{
Ole-Kristian Hope \\ Rotman School of Management \\ University of Toronto \\ okhope@rotman.utoronto.ca \\ Wayne Thomas \\ Michael F. Price College of Business \\ University of Oklahoma \\ wthomas@ou.edu \\ Dushyantkumar Vyas \\ Rotman School of Management \\ University of Toronto \\ Dushyantkumar.Vyas06@rotman.utoronto.ca
}

May 14, 2008

\begin{abstract}
Using an extensive panel of cross-border M\&A transactions between 1990 and 2007, we find that firms from developing countries (versus those from developed countries) bid higher on average to acquire assets in developed countries. We are interested in why these higher bids occur. We find that bids of firms from developing countries are higher in cases where the transaction displays "national pride" characteristics, where national pride is identified through a manual examination of media articles. While other factors may also influence these higher bids, we find that the role of national pride is robust across a number of specifications and control variables. These results highlight a source of pride beyond personal hubris which potentially influences corporate decision makers.
\end{abstract}

\section{Acknowledgments}

We have received useful comments from Laurence Booth, Feng Chen, Russell Craig, Gus De Franco, Alexander Dyck, Evgenia Golubeva, Paul Halpern, Emre Karaoglu, Jan Mahrt-Smith, William Megginson, Rina Ray, Wendy Rotenberg, Wolfgang Schultze, Han Yi, and seminar participants at University of Oklahoma, the IAS meeting (San Diego), and the EAA meeting (Rotterdam). Hope gratefully acknowledges the financial support of the Deloitte Professorship. 


\section{Introduction}

In recent years, mergers and acquisitions (M\&A) activity has increased sharply around the world. The late 1990s witnessed an unprecedented merger wave, which peaked in the year 2000 at $\$ 3.4$ trillion. After a brief period of decline, M\&A activity is on a steep rise once again and reached $\$ 3.8$ trillion in $2006 .{ }^{1}$ Cross-border M\&A activity has increased proportionately and accounts for almost a quarter of the global M\&A volume. ${ }^{2}$ According to the United Nations Conference on Trade and Development (UNCTAD), a recent and interesting feature of this cross-border M\&A wave is the series of high-profile bids by firms from developing countries. M\&As are becoming an important way to enter foreign markets by firms from developing and transition economies. ${ }^{3}$ Between 1987 and 2005, the share of developing and transition economies in global cross-border M\&A activity rose from $4 \%$ to $13 \%$ in value terms, and from $5 \%$ to $17 \%$ in terms of the number of deals.

Some of the bids originating from developing countries have been accompanied by a huge media frenzy, political interference, and nationalistic talk (both in the acquiring and target country). Notable examples are the bid for Unocal by Chinese-owned CNOOC, media hype and national security concerns in the United States surrounding the acquisition of P\&O by DP World from the United Arab Emirates, xenophobia surrounding the acquisition of Europe-based Arcelor by Mittal Steel, and national pride considerations in Tata Steel's acquisition of U.K.'s Corus. While these deals are examples of increasing financial power and confidence in the bidding countries, it remains an open question whether these companies bid higher (relative to companies from developed countries) in their quest for international expansion and perhaps national glory. For example, media articles about the Tata Steel - Corus deal suggest that nationalist

\footnotetext{
${ }^{1}$ Source: Thomson Financial M\&A Review, Fourth Quarter 2006.

${ }^{2}$ Source: UNCTAD, World Investment Report Overview 2007, page 5.

${ }^{3}$ Source: UNCTAD, World Investment Report 2006, page 108 - 109.
} 
considerations seem to have influenced the bidding process. In the words of Ratan Tata, Chairman of Tata group after acquiring Corus - (Financial Times, February 3, 2007):

"We all felt that to lose would go beyond the group and it would be an issue of great disappointment in the country. So on the one hand, you want to do the right thing by your shareholders and on the other hand, you did not want to lose."

In this paper, we first examine whether companies in developing countries (versus those from developed countries) tend to bid more for assets in the developed world. We find that the bid premium from developing countries is higher, but why does this occur? While several reasons may exist, we are interested in the role of national pride in driving up bids for firms in developed countries. Researchers have documented that there is a natural tendency to seek pride in investment decisions. ${ }^{4}$ While individual pride might be a determinant of higher bids in general, we investigate whether display of national pride plays a role in magnifying the effects of individual pride, and consequently, the tendency of managers to "empire build." Hence, in addition to the research on pride at the individual level, we also appeal to a line of research that investigates effects of pride at the national level. The impact of national pride on bid premiums has not been investigated in the literature.

Smith and Kim $(2006,127)$ define national pride as "the positive affect that the public feels towards their country, resulting from their national identity. It is both the pride or sense of esteem that a person has for one's nation and the pride or self esteem that a person derives from one's national identity." Researchers have argued that national pride plays a role in influencing

\footnotetext{
${ }^{4}$ Kahneman and Tversky (1979), Thaler (1992), and Benartzi and Thaler (1995) provide many useful references to this literature.
} 
attitudes towards international economic issues (e.g., Müller-Peters 1998). If national pride influences individual pride (and as a consequence, economic decision making), then we would expect to see the effects at the decision level. This forms the basis of our research question does national pride influence M\&A bids emanating from developing countries? To the best of our knowledge, this is the first study to investigate the higher bids by firms from developing countries to acquire assets in developed countries and the role of national pride. We consider the identification of national pride as a determinant of bid premiums to be a key contribution of the paper.

Using a large sample of cross-border M\&A transactions between 1990 and February 2007, we construct a novel measure of national pride by examining media articles about each bid in our sample. We are thus able to identify and measure nationalistic and political considerations surrounding some of these high-profile bids. We find that this variable positively and significantly impacts the bid premium by firms from developing countries. Our results are robust to controls for the impact of institutional mechanisms, differences in shareholder protection, cultural differences, excess media coverage, and numerous other firm and bid characteristics, and to a variety of sensitivity analyses, including whether firms are politically connected. We do not find evidence that bids of firms from developing countries (versus those from developed countries) are higher for targets in developing countries. Thus, bids from developing countries are not always higher in general. This result supports the natural belief that national pride should have a greater effect on bid premiums only when firms from developing countries bid on assets in developed countries.

The rest of this paper is organized as follows. Section 2 discusses the related literature. Section 3 describes the data and sample. Section 4 presents the research design and results of 
main tests and additional analyses. Section 5 concludes.

\section{Related Literature}

This paper draws upon the economics, finance, international business, strategy, and psychology literature dealing with the characteristics of M\&A transactions and international economic activity. Several prior studies document that acquisition premiums in general appear to be too high. Researchers such as Roll (1986) commonly refer to this phenomenon as the “winner's curse" or the "hubris hypothesis." Roll (1986) asserts that the acquirer's managers are overly optimistic about the value of combining their company with the target and therefore are willing to pay an amount that is too high. In other words, managers' overconfidence (i.e., hubris) results in them being unwilling to abandon bids that represent positive valuation errors. According to Roll's hypothesis, managers might behave like "Empire Builders" (see also Schumpeter 1911; 1934; Baumol 1959; Williamson 1974; Jensen 1986; Hope and Thomas 2008). As an example of the effects of overconfidence/hubris, Malmendier and Tate (2008) have recently documented that "overconfident" CEOs are more likely to indulge in (potentially valuedestroying) acquisitions (see also Grinblatt and Keloharju 2008).

One reason that managers have incentives to build empires is that they personally gain by increasing the resources under their control, which could increase their compensation, power, and prestige and decrease their unemployment risk (Amihud and Lev 1981; Murphy 1985; Baker 1986; Shleifer and Vishny 1989; Stulz 1990; Jensen and Murphy 1990; Rose and Shepard 1997; Bebchuk and Grinstein 2005). Furthermore, research shows that agency costs associated with managerial empire building behavior are more severe when corporate governance is weaker (Jiraporn, Kim, Davidson, and Singh 2006) and managers are less accountable to their 
shareholders (Lombardo and Pagano 2002; Hope and Thomas 2008). ${ }^{5}$

One form of empire building is growing the firm by engaging in cross-border acquisitions. Managers from developing countries could have more freedom to build an empire through cross-border acquisitions, because corporate governance is less likely to constrain managerial behavior. La Porta, Lopez-De-Silanes, Shleifer, and Vishny (1997), Ball Robin, and Wu (2003), and Bushman, Piotroski, and Smith (2004), among others, provide evidence that the quality of corporate governance is lower in developing countries.

Beyond building an empire at the firm level, managers from developing countries may have an added incentive to build an empire for their country. These managers may feel an obligation to the government or society in general to raise the status of their country by acquiring assets of a company from a developed nation. For example, in many developing countries, there are national pride implications of acquiring a company from the U.S. or the U.K. Such acquisitions may be seen as landmark movements in improving overall social welfare, regardless of the cost to the individual firm. ${ }^{6}$ The influence of national pride on the individual pride of decision makers (or a sense of patriotism and duty towards the nation) leads to the expectation of bid premiums being greater when national pride considerations are present. ${ }^{7}$

A large literature in psychology demonstrates the effects of emotions on decision making (see Loewenstein (2000) and Lerner and Keltner (2000) for extensive references to this

\footnotetext{
${ }^{5}$ The link to empire building can also be found in the literature on global diversification, which points towards the existence of a geographic diversification discount (e.g., Denis, Denis, and Yost, 2002).

${ }^{6}$ In an interview (Hindu Business Line, February 1, 2007), the Indian Finance Minister P. Chidambaram expressed joy on the completion of the Tata-Corus deal by saying "We are happy that the Tatas have emerged as the successful bidder." See also "The Romance of Tata Steel" by R.M. Laia (Penguin, India, 2007) which states that "the company (Tata Steel) has been associated with the development of the Indian nation as no other company in India."

${ }^{7}$ Research has shown that pride at both the individual and national level has the potential to affect economic decisions. Since decision makers in corporations, governments, and institutions are individuals, the effect of national pride on decision making should be through its effect on individual pride. In other words, even if the general public in a particular country has a high level of national pride or patriotic sentiment, unless the individual manager or decision maker displays the same sentiment, we do not expect an economic effect on the specific issues under consideration. Thus, in this paper, our analysis focuses on the effects of national pride on decision making by individuals - or in other words, the effect of national pride in magnifying individual pride.
} 
literature). More specifically, psychology research has established that individuals seek positive distinctiveness (this is referred to as social identity theory), and this could be considered a basis of pride (Tajfel and Turner 1979; Ellemers, Spears, and Doosje 1999; Ellemers, Spears, and Doosje 2002). In marketing research, studies show how buying decisions are affected by pride (e.g., Louro, Pieters, and Zeelenberg 2005; Mukhopadhyay and Johar 2007), and in behavioral finance the literature tests the effect of pride, often in conjunction with the "disposition effect" (e.g., Odean 1998).

While the impact of individual pride (or hubris) on economic decision making has been a burgeoning area of research, there are relatively fewer studies investigating the effects of pride at the societal or national level. Müller-Peters (1998) documents that European countries that score higher on national pride (i.e., nationalistic stance in his study) have a more negative attitude toward the Euro. The marketing literature discusses the role of national pride and patriotism in consumer decision making. For example, Zhang (1996) states that "national pride, loyalty, and patriotism have been found to influence consumers' reactions to foreign products. Consumers often exhibit a preference for products produced in the home country even though home country products do not necessarily have the best quality or price" (see also Gaedeke 1973; Darling and Kraft 1977; Wall and Heslop 1986). Our study adds to this literature by testing whether bid premiums are higher in cases where media articles allude to nationalistic sentiments or national pride as a consideration. As discussed in the subsequent section, we consider media citations of nationalistic sentiments as indicators of national pride.

\section{Data and Sample}

The characteristics of the cross-border bid transactions examined in this paper are 
obtained from the SDC Platinum (Mergers and Acquisitions) database. To classify bidders from “developing" or "developed" countries, we use the United Nations Statistics classifications. ${ }^{8}$ We obtain the sample using the following data restrictions: (1) the deals / bids are cross-border as identified by the SDC cross-border flag, (2) bids are for targets in developed countries, (3) data required for computing the bid premium are available, (4) data required to compute the control variables described below are available, and (5) the bid premium is greater than zero, where the bid premium is defined as the bid price per share divided by the target's closing price four weeks prior to the bid announcement, minus one. ${ }^{9,10}$ Restriction (5) is employed to ensure the reasonableness of the bid premium data. These criteria result in a sample of 3,806 bids for targets in developed countries over the $1990-2007$ period. ${ }^{11}$ Approximately $8 \%$ of the bids are by firms from developing countries, while the remaining bids are by firms from developed countries. ${ }^{12}$ To investigate whether national pride is a cross-sectional determinant of the bid premium, we select only the bids made by firms from developing countries for targets in developed countries. This reduces our sample to 295 bids. We identify bids accompanied by nationalistic considerations through a direct examination of media articles surrounding the bid on Factiva. ${ }^{13}$

\footnotetext{
${ }^{8}$ Source: http://unstats.un.org/unsd/methods/m49/m49regin.htm\#developed

${ }^{9}$ The use of a four week window to measure the bid premium addresses issues pertaining to early leakage of news regarding the bid and rumors, if any. It is also consistent with prior studies such as Rossi and Volpin (2004). Section 4.4.2 reports results of using alternative measurement windows.

${ }^{10}$ The measure of bid premium using SDC price data is criticized by Officer (2003) on grounds that it is has a tendency of reporting outliers below zero (an economically reasonable lower bound) and greater than $100 \%$. We address this criticism by using premiums greater than zero and by reporting sensitivity analyses after deleting or winsorizing extreme observations.

${ }^{11}$ Our data requirements imply that the target firms in our sample are all public firms, whereas bidder firms could be public or privately held.

${ }^{12}$ Some acquirers form a special purpose entity in another country for purposes of the acquisition. An example is the formation of AV Aluminum in Canada by India-based Aditya Birla group to acquire the Canadian firm Novelis. We have classified this as an acquisition by an Indian firm of a Canadian firm. Similarly, based on anecdotal evidence surrounding the Mittal-Arcelor bid, we decided to classify Mittal Steel as an Indian firm based on the nationality of its principal owner, rather than the country in which that firm is head-quartered or listed (our results are however robust to employing the alternate classification for this bid).

${ }^{13}$ Factiva is a widely used source for media coverage in current and recent international research (e.g., Chan 2003; Bhattacharya, Galpin, Rina, and Yu 2008; Dyck, Volchkova, and Zingales 2008). For example, Bhattacharya et al.
} 
We use the following search algorithm in Factiva:

- Search string: "Target's name” AND "Bidder's name”

- Date range: Three months prior to the date of announcement to three months following the date of announcement ${ }^{14}$

We then manually examine the resulting articles to check for prevalence of nationalistic sentiments relating to the deal on either side. The identification primarily relies upon a manual "headline search." Once the potential national pride bids are identified from the headlines, we study the media article in detail to reconfirm the existence of national pride sentiments surrounding the bid. In addition to direct mention of national pride in these media citations, we exercise our judgment in classifying some bids as national pride bids on the basis of indications of national political considerations surrounding the bid. Our identification of national pride does not distinguish between pride on the bidder side or the target side.

A complete listing, along with relevant excerpts from the media articles can be obtained from the authors upon request. ${ }^{15}$ Based on this detailed examination, we identify 36 bids (out of 295) as "national pride bids."

As an example of display of national pride considerations on the bidder side, consider the following:

Publication: Times of India, 24 March 2007

$(2008,7)$ state that Factiva "does not suffer from gaps in coverage and is the best approximation of public news for general investors."

${ }^{14}$ We note that articles that might indicate national pride considerations often appear after the bid has been announced. Hence, for our direct identification of national pride, we examine news articles both before and after the bid announcement date.

${ }^{15}$ We do not distinguish between whether the reporting media is local or international. Also, for practical reasons (and following extant research) our search is limited to articles written in English. As such, our search procedure could miss out on potential variation that could be observed by a more thorough examination of news articles in local languages. 
Headline: "Tata buys Chrysler.”

\section{Indication of national pride:}

"When Ratan Tata bought Corus last month, he got the entire steel industry of Britain and Holland and earned the applause of an India bent on assuming a place in the world. He paid too much but he called it 'a moment of great fulfilment for India.' Two weeks later, Kumar Birla bought Novelis to become the world leader in rolled aluminium from which cans of Coke and Pepsi and cars are made. Once again national pride was on display. Are these purchases smart business buys? Or is it about personal egos and national honour?"

The bidder and target country-wise distribution of the 295 bids by firms from developing countries (for targets in developed country) is provided in Panel A of Table 1. Panel B gives a similar distribution for the 36 national pride deals. ${ }^{16}$

\section{Research Design and Results}

\subsection{Bid premiums from developing countries versus developed countries}

To examine whether firms from developing countries (versus from developed countries) pay a higher premium when bidding for firms from developed countries, we adopt and expand on the empirical model used by Rossi and Volpin (2004). The following regression model is estimated:

$$
\log (\text { Premium })=a+b *(\text { Developing country })+c *(\text { Control variables })+e
$$

\footnotetext{
${ }^{16}$ Untabulated statistics show that the 295 bids are quite evenly spread across years (except for a peak in 2006 representing $12 \%$ of the sample firms). The 36 cases classified as national pride bids are also quite evenly distributed over time (with peaks in 1995 and 2006).
} 
We regress the log of the bid premium, as defined previously, on an indicator variable for the bidder's country status (equal to one for developing country and zero otherwise). We include control variables identified by prior literature. The theoretical model employed by Grossman and Hart (1980) motivates the controls for the target's profit-generating capacity under the existing management. These controls include target firm size (log of net assets), target current profit margin, and target industry fixed effects using two-digit SIC codes (to account for growth characteristics and other industry effects). We also introduce several controls for deal-specific characteristics that could influence the transaction. Consistent with Rossi and Volpin (2004), we control for the existence of competing bids, tender offers, whether the bid is hostile or not, and whether the bid is for cash or stock. Walkling and Edmister (1985) suggest that bid premiums are expected to be higher for successful (or accepted) bids and bids which seek control of greater than 50\%. Accordingly, we include the outcome of the bids (successful or not) and the percentage of outstanding shares sought as control variables. ${ }^{17}$ We further control for whether the buyer is a financial institution or not (since bids made by financial buyers are more likely to be purely for investment purposes). In addition, to control for unknown country variation we also report results using target country fixed effects. Finally, we include year fixed effects in all models.

In a second version of our empirical model, we replace target country fixed effects with the target country's level of shareholder protection (e.g., Bris, Brisley, and Cabolis 2008; Rossi and Volpin 2004). Following Rossi and Volpin (2004), we measure shareholder protection as "Anti-director rights" multiplied by "Rule of law" divided by 10 (where Anti-director rights and

\footnotetext{
${ }^{17}$ Though we use a control for the outcome of the deal (successful or unsuccessful), in other sensitivity tests we examine if our results on national pride hold true if we exclude unsuccessful bids (i.e., bids that were not accepted). We find that inferences are unaffected when only considering successful bids.
} 
Rule of law are as defined in La Porta, Lopez-De-Silanes, Shleifer, and Vishny 1998).

Similarly, in the third version of the model, we replace target country fixed effects by controls for differences in culture between the bidder's country and the target's country. This control is motivated by research on culture and economic decision making. Guiso, Sapienza, and Zingales (2006) use tests based on the relative trust that European citizens have for other countries in Europe. The authors contend that differences in culture, religion, and genetic history affect trust between different sets of people. They establish that perceptions about people from different countries are important determinants of economic exchange, and argue that lower levels of trust lead to less trade and less foreign investment, perhaps suggesting the need for a higher bid premium. The results in Morosini, Shane, and Singh (1998) also suggest that differences in culture may lead to higher bid premiums. They find that greater differences in culture between the acquirer and target lead to higher post-acquisition performance. For these reasons, we control for cultural differences when testing for differences in bid premiums. ${ }^{18}$ To calculate cultural differences, we employ a summary measure of Hofstede's (1980) cultural distances as employed by Chakrabarti, Jayaraman, and Gupta-Mukherjee (2008). Specifically, we define cultural distance between the bidder and the target country as the square root of the sum of squared distances on the four Hofstede cultural dimensions, divided by four.

All control variables are defined in Table $2 .{ }^{19}$ Table 3, Panel A, presents descriptive statistics of cross-border deals for our full sample. To control for the potential impact of extreme bid premiums, in all of our empirical tests we employ the log of 100 times the bid premium. Approximately $8 \%$ of the bids had a competing bid, $78 \%$ of the bids were successful bids, $5 \%$ of

\footnotetext{
${ }^{18}$ Many studies document that national culture affects managerial decisions in a variety of settings (e.g., Hofstede 1980; Gray 1988; Salter and Niswander 1995; Stulz and Williamson 2003; Hope 2003; House, Hanges, Javidan, Dorfman, and Gupta 2004).

${ }^{19}$ In Section 4.4.1 we report that results are robust to including several additional controls in our empirical models.
} 
the bids were termed as hostile or unfriendly, and 58\% were cash bids. Table 3, Panel B, reports descriptive statistics for bids by developing country firms for targets in developed countries. Compared with the full sample in Panel A, the bid characteristics are similar: $8 \%$ had competing bids, $78 \%$ were successful, $3 \%$ were termed as hostile or unfriendly, and $56 \%$ were for cash.

Panel C presents Pearson correlations for our sample of 295 bids. Bid premiums are significantly positively correlated with our direct measure of national pride (at less than the one percent level). Correlation results should be interpreted cautiously as they do not control for differences in firm characteristics over time or in the cross section. Consequently, we next turn to multivariate tests.

Panel A of Table 4 presents the results of model (1). We use Huber-White standard errors that are adjusted for clustering at the firm (bidder) level in all models. ${ }^{20,21}$ The coefficient on the developing country indicator is positive and significant at the 0.10 level (using a two-tailed test). This result indicates that bids from firms in developing country are $16 \%$ higher than their counterparts in developed countries for targets in developed countries. ${ }^{22}$ This result holds after controlling for a large number of potentially confounding variables and controlling for year, target country, and target industry fixed effects (column I). ${ }^{23}$ In line with the findings in the prior literature, bid premiums tend to be higher for higher percentage stake sought, in the presence of a competing (rival) bid, or for tender offers. Bid premiums tend to be lower for targets with higher net assets or if the bidder is a financial institution.

\footnotetext{
${ }^{20}$ We have also run tests with standard errors clustered by (1) target two-digit SIC code, (2) bidder nation, and (3) target SIC code-bidder nation. The national pride indicator remains significant under all standard error specifications.

${ }^{21}$ There is no significant multicollinearity present in any of the results shown in the paper. Specifically, the highest variance inflation factor for any of our key independent variables in the regression tests reported is 2.92 .

${ }^{22}$ Recall that the dependent variable in our tests is the natural logarithm of the bid premium. Thus, a coefficient of 0.149 translates into a $16 \%$ higher premium.

${ }^{23}$ Untabulated statistics show that country, year, and industry fixed effects are significant at the five percent level or better.
} 
Next, we replace target country fixed effects with the target country's shareholder protection (column II) and cultural distance from the bidder (column III). We find that the developing country indicator variable remains significantly positive. Consistent with Rossi and Volpin (2004), we find that the level of shareholder protection in the target country is significantly positively related to bid premiums. Bid premiums are not related to cultural distance. In summary, we find that the developing country indicator variable captures dimensions over and above institutional and cultural differences (as well as numerous other controls).

Next, we consider whether bids from firms in developing countries are higher in general, and not only for targets in developed countries. It could be that bid premiums from developing countries are systematically higher than those from developed countries because of differences in macroeconomic factors such as tax effects (Scholes and Wolfson 1990), accounting procedures (Robinson and Shane 1990), or exchange rate movements (Froot and Stein 1991; Harris and Ravenscraft 1991). To examine this, we repeat our tests by comparing the bids of firms from developing versus developed countries for targets in developing countries. National pride sentiments are less likely to arise when the target is from another developing country (say for example, a Malaysian firm bidding for an Indonesian firm). Apart from the existence of national rivalries and unknown prejudices, we have no reason to expect national pride to be a determinant of bid premiums when the target lies in a developing country, and therefore do not expect bid premiums to differ.

As can be observed from Panel B of Table 4, the coefficient on the developing country indicator variable is no longer significant when the sample includes targets in developing 
countries only. ${ }^{24}$ In other words, bidders from developing countries do not always bid more in general; they bid more only when acquiring targets in developed countries. The lack of a difference in bid premiums for targets in developing countries strengthens our belief regarding the importance of national pride on bid premiums for targets in developed countries.

\subsection{Effect of national pride on bid premiums from developing countries}

To address our research question of whether national pride (through its influence on individual managers' decision making) is associated with the bid premium, we restrict our sample to bids from developing countries for targets in developed countries. For this smaller sample, we estimate the following model:

$$
\log (\text { Premium })=a+b *(\text { National pride })+c *(\text { Control variables })+e
$$

As described earlier, the indicator variable National pride takes a value of one when manual examination of media articles reveals national pride considerations associated with the deal. We include the same set of control variables and model estimation procedures employed in our full sample tests.

Table 5 presents the results of model (2). We find that the bid premium increases significantly with displays of national pride. Specifically, we document a positive coefficient (0.656) on national pride in column I, which is significant at the 0.01 level (using a two-tailed

\footnotetext{
${ }^{24}$ In a pooled test (including both developed and developing targets), the coefficient is positive and significant for developing country acquisitions of developed targets but not significant for developing country acquisitions of developing targets.
} 
test). ${ }^{25}$ In addition to being statistically significant, national pride also appears to be economically important. That is, everything else remaining the same, the premium associated with national pride bids is almost twice that of the premium associated with non-national pride bids. This finding supports our hypothesis that national pride considerations significantly affect bid premiums. Similar to our analysis in the first stage, we sequentially introduce controls for target shareholder protection and cultural distance and find that conclusions do not change. We find that shareholder protection is positively related to premiums, but only marginally significant and only when cultural distance is not included in the model. Cultural distance is not significant. Of other control variables, both the percentage sought and the existence of a competing offer are consistently positively and significantly associated with bid premiums, and target firm size is negatively related to premiums. ${ }^{26}$

\subsection{Tests using media coverage measures}

Although the above measure is the most direct and thus our primary proxy for national pride, we also construct indirect (and more easily measurable) statistical indicators of national pride. Consistent with anecdotal support discussed in section 2, we expect that deals accompanied by nationalistic considerations are likely to generate excessive media publicity. ${ }^{27}$ As such, our first indirect proxy for national pride is the raw media coverage associated with the

\footnotetext{
${ }^{25}$ Since our dependent variable is truncated at zero (i.e., we only include positive premiums), as a robustness test we reestimate the empirical tests using Tobit instead of OLS. National pride remains positive and significant (at the 0.01 level using a two-sided test) in all these tests.

${ }^{26}$ Untabulated statistics show that both country and industry fixed effects are significant at the one percent level and that year fixed effects are not significant.

${ }^{27}$ For a practical example of this line of argument, see for example, "Corus deal takes India euphoric," Anand Giridharadas, International Herald Tribune, February 1, 2007. The article states that: "As ever more Indian acquisition deals were announced, most of them smaller and less controversial, a kind of takeover nationalism emerged. This has hit its zenith, perhaps, with a new marketing campaign by The Times of India called "India Poised" ....." See also "Fighting economic nationalism in deals," Laurence Capron and Mauro Guillén, Financial Times, October 12, 2006. The article states that: "The Mittal-Arcelor battle inspired an exceptional media frenzy, but it is not an isolated case..."
} 
bid. To calculate media coverage, we obtain a count of media articles on Factiva on the basis of the search algorithm explained above. We use a time period of three months prior to the date of bid announcement to the date of bid announcement.

While we find that media coverage is positively correlated with national pride, it is likely to be only a weak proxy for our direct measure of national pride. ${ }^{28}$ In other words, media coverage measures are likely to contain components that are unrelated to our direct measure for national pride. To that extent, excess media coverage serves not only as an additional proxy for national pride, but also serves as an additional control variable when used in conjunction with the direct measure. To avoid potential endogeneity concerns in attributing additional premium to excess media coverage, we do not count articles after the date of announcement.

Thus we estimate the following equation:

$$
\log (\text { Premium })=a+b^{*} \log (\text { Media coverage })+c^{*}(\text { Control variables })+e
$$

Column I of Table 6 reports the results and shows that raw media coverage surrounding the event is positively and significantly associated (at the 0.05 level using a two-tailed test) with bid premiums. This result is consistent with and corroborates the result using the more direct measure of national pride.

To further address potential endogeneity in attributing higher media coverage to higher premiums, we follow an approach similar to Dyck, Volchkova, and Zingales (2008). In particular, we calculate excess media coverage by using a one-year period from 12 to 24 months prior to the bid announcement date as a "quiet period" and identify the article count in that

\footnotetext{
${ }^{28}$ The Pearson correlation between national pride and media coverage (excess media coverage) is $0.159(0.126)$ with a two-sided p-value of 0.006 (0.031).
} 
period (divided by four) as the intrinsic level of "newsworthiness" for both the bidder and the target. The logarithm of raw media coverage three months prior to the date of announcement to the date of announcement is regressed on the logarithm of the newsworthiness of the target and the bidder during the $12-24$ months prior to the announcement.

$$
\begin{gathered}
\log (\text { Media coverage })=a+b^{*} \log (\text { Bidder newsworthiness })+c^{*} \log (\text { Target } \\
\text { newsworthiness })+e
\end{gathered}
$$

The residual obtained from model (4) provides our measure of excess media coverage (i.e., $e=$ Excess media coverage $).{ }^{29} \mathrm{We}$ use this measure as another proxy for national pride and estimate the following equation.

$$
\log (\text { Premium })=a+b *(\text { Excess media coverage })+c *(\text { Control variables })+u
$$

Column II of Table 6 shows that this alternative (and indirect) measure of pride is also positively and significantly associated with bid premiums (at the 0.10 level using a two-tailed test). The results are robust to inclusion of all the control variables described in the previous section. We note that our direct measure of national pride is economically and statistically more significant than are the measures that employ media coverage as a proxy. We believe that this is due to media coverage measures likely being noisier due to reasons other than national pride.

Finally, to control for the possibility that our direct measure of pride only proxies for our

\footnotetext{
${ }^{29}$ The adjusted $\mathrm{R}^{2}$ of this regression is 0.33 .
} 
indirect measure (excess media coverage), in column III we include both measures jointly. ${ }^{30}$ Our direct measure continues to be positive and significant even in the presence of excess media coverage. These results are important as they demonstrate that our direct measure of national pride, as identified using the content of media articles, remains significant when controlling for the count of media articles. This gives us greater confidence that national pride, beyond some other correlated M\&A publicity variable, is a determinant of bid premiums. ${ }^{31}$

\subsection{Sensitivity analyses}

\subsubsection{Political connections}

Based on the evidence provided in this paper, it appears that nationalistic considerations play an important role in explaining the higher bid premiums paid by firms in developing countries. While the existence of national pride considerations could be interpreted as "irrationality" on part of the bidding firms, we cannot rule out the existence of more fundamental underlying rational motives.

For example, one line of reasoning could be that these bidding firms are simply furthering the nationalist agenda of their respective national governments. In return, the governments could reward them with economic incentives (like tax benefits, license granting, and reduced bureaucracy, among other things). Evidence on the role of political linkages in firm valuation can be found in Fisman (2001), who documents the impact of political links on firm

\footnotetext{
${ }^{30}$ Our media coverage measures could also be viewed as additional controls for variations in (firm-level) corporate governance (e.g., Dyck et al. 2008).

${ }^{31}$ As an alternative to the more direct time-series based measure, we have also used a cross-sectional measure of excess media coverage that controls for target firm size as well as industry, year, and country fixed effects. More specifically, we estimate the following model: $\log ($ Media coverage $)=a+b^{*} \log ($ Target book value) $+c^{*}($ Industry effects $)+d^{*}($ Year effects $)+e^{*}$ (Target nation effects $)+f^{*}($ Bidder nation effects $)+h$ The residual $(h)$ obtained from the above equation is then used as an alternative measure of national pride. In untabulated tests we observe that the statistical significance of this variable is greater than the earlier measure of excess media coverage based on model (4) and that our direct measure of national pride remains positive and significant at the one percent level when the two variables are jointly included.
} 
value in Indonesia, a country with a weak legal system. Additional evidence can be obtained in Leuz and Oberholzer-Gee (2006), who argue that political connections alter a firm's financing strategies and long-term performance (see also Fan, Wong, and Zhang 2007).

In an interesting recent study, Faccio (2006a) examines the role of political connections in 47 countries (see also Faccio 2006b; Faccio, Masulis, and McConnell 2006). She finds that corporate political connections are relatively widespread; they exist in 35 of the 47 countries in her sample. Connections are particularly common in countries that are perceived as being highly corrupt and in countries that impose restrictions on foreign investments by their citizens. They are less common in the presence of more stringent regulation of political conflicts of interest. She further shows that the announcement of a new political connection results in a significant increase in value.

To test whether political connections can explain our results for national pride, we have matched our sample with that of Faccio (2006a). ${ }^{32}$ Faccio (2006a) defines a company as politically connected if at least one of its large shareholders (anyone controlling at least 10 percent of voting shares) or one of its top executives (CEO, president, vice-president, or secretary) is a king, president, or minister in the government, has a close relationship with a politician, or is a member of parliament. Of our sample of 295 bids, only ten are coded as coming from firms that are politically connected, as documented by Faccio. Five of these ten firms are among our 36 national pride bids. To test for the possibility that our national pride results are driven by firms with political connections, we have added an indicator variable for political connections as an additional control variable to our tests. We find that national pride

\footnotetext{
${ }^{32}$ We thank Mara Faccio and The American Economic Review for making these data available.
} 
retains its significance and that the political connection variable is not significant. ${ }^{33}$ Although not exhaustive evidence, this result provides some support for the notion that our results are more likely related to national pride rather than economic incentives of the government.

\subsubsection{Additional controls ${ }^{34}$}

As explained above, our tests include a rich set of control variables. However, to further minimize the possibility that our results may be driven by some "other" (and correlated) variable that has been omitted from our analyses, we consider a number of additional control variables.

We first examine whether bid premiums relate to a measure of national pride at the country level. Specifically, we use the "World Values Survey" and in particular include the percentage of respondents in each country who said that they are "very proud" of their nation (either in percentage terms or as a rank measure) ${ }^{35}$ We find that this country-level variable is not statistically significantly correlated with bid premiums and that all inferences remain when adding this variable as an additional control. This result highlights the importance of measuring the effects of national pride on bid premiums using the content of media articles. While differences in overall national pride may remain fairly constant across countries, it is easy to envision M\&A activity invoking greater variation in national pride, especially ones that involve a company in a developing country acquiring a company in a developed country. Our measure of national pride is deal-specific, and country-level measures may be too coarse to detect these effects. Consistent with this idea, we note that the correlation between our measure of national

\footnotetext{
${ }^{33}$ As an additional test we have rerun the regression after dropping firms with political connections. No inferences are affected with this alternative specification.

${ }^{34}$ Please note that, although we comment on each additional control variable separately, the national pride indicator remains positive and significant (at the one percent level) also after including all these controls in the same regression.

${ }^{35}$ Source: European And World Values Surveys Four-Wave Integrated Data File, 1981-2004. 2006. The European Values Study Foundation and World Values Survey Association.
} 
pride and the one from the World Values Survey is only 0.02 and is not significant.

Second, we consider the possibility that the existence of national pride deals is related to the overall history of cross-border M\&A from a particular country. If cross-border deals from a country become more common, the likelihood that such deals are accompanied by national pride could diminish. Alternatively, managers from countries that are relatively inexperienced in crossborder M\&A might value targets differently from those that have more experience in crossborder deals. To account for this possibility, we define a variable which captures the extent of novelty in the occurrence of cross-border M\&A from a bidding nation. For each bidding nation, this variable takes on a value equal to the number of years for which the cross-border M\&A volume from 1990 to 2005 equals zero. The more the number of years for which the value of outbound M\&A is zero, the more novel (or less common) would be the occurrence of M\&A. We add this variable as a control variable in our national pride tests and find that its estimated coefficient is not significant. More importantly, our inferences are unaltered by the inclusion of this variable.

Third, it is conceivable that the bid premium might be affected by whether the bidding firm is from the same industry as the target (Harris and Ravenscraft 1991). ${ }^{36}$ To test this, we employ an additional control variable which takes on a value of one for bids where the bidder and target are from the same two-digit SIC code. We find that this variable is insignificant in all our tests and that all our inferences are unaltered. ${ }^{37}$

Fourth, we control for two ownership characteristics: whether the bidder is publicly listed

\footnotetext{
${ }^{36}$ Recall that all our tests include target industry fixed effects.

${ }^{37}$ While $26 \%$ of the national pride bids are in the mining industry (SIC codes 10 to 14), $17 \%$ of the overall bids from developing countries are in mining. We further observe that premiums are lower for mining firms (significant at the 0.01 level). As an alternative to including target industry fixed effects in our models, we estimate the regression after including a control for the mining industry. National pride remains significant, both economically and statistically.
} 
or privately held and whether the bidder is a government-controlled entity or not. We find that premiums are negatively associated with the privately held status (significant at the ten percent level) and negatively but not significantly related to government control. ${ }^{38}$ Most importantly, our main results remain the same.

While we include target industry and target nation fixed effects to proxy for a wide variety of effects including risk and growth opportunities, as a final test we repeat our tests by augmenting these macro-level indicators by target firm-specific measures of risk and growth opportunities - leverage (long term debt divided by total assets) and the market-to-book ratio (e.g., Kwok and Reeb 2000). ${ }^{39}$ Neither of these additional controls loads. The inferences on national pride remain strong.

\subsubsection{Other sensitivity analyses}

First, since there is some debate over the classification of countries as developed or developing, as a sensitivity check for the first-stage results, we replace the developing country indicator by differences in GDP per capita (between bidder and target nations). Untabulated analysis shows that no inferences are affected by instead using this continuous measure.

Our other sensitivity tests relate primarily to our main test: the effect of national pride on bid premiums. For our second sensitivity analysis, we conduct several robustness tests related to the measurement of bid premiums. With respect to the time windows for measuring the bid premium, we repeat our tests using one week and one day windows to measure the premium (as opposed to the four week window reported in our tabulated results) and find that our inferences

\footnotetext{
${ }^{38}$ In our sample of 295 firms, there are 42 private firms and 44 government-controlled firms (i.e., more than $50 \%$ of the shares are owned by a government). Of the 36 national pride firms, seven are private firms and two are government entities.

${ }^{39}$ The main reason for not including these controls in our main test is that the sample size decreases significantly (to 175) when requiring these additional variables.
} 
remain the same. We also test whether our results are sensitive to outlying observations for bid premiums. In particular, our tests show that the results are similar after either winsorizing or deleting the top and bottom $1 \%$ of the premium observations.

As a third sensitivity check, we repeat our tests after deleting observations that involve bids by firms from Hong Kong for Chinese firms (since it can be argued that these are within country bids). There are 32 such bids in our sample (22 from post 1997). No inferences are affected by excluding these observations. ${ }^{40}$

Fourth, although we use a control variable for the outcome of the deal (successful or unsuccessful), as an additional test we examine if our results for national pride hold true if we exclude unsuccessful bids. We find that the national pride indicator remains positive and significant also after dropping unsuccessful bids from our sample.

Fifth, in our main tests we control for target country shareholder protection. This approach is consistent with Rossi and Volpin (2004). However, the difference in shareholder protection between the bidder and target nation potentially better captures differences in corporate governance structures. Consequently, in additional analyses we use the difference in shareholder protection as an alternate control. Our results are robust to this variable.

Finally, we replace book value by the logarithm of sales as our control for firm size, and we use a continuous variable for the percentage of cash offered in the bid instead of an indicator for instances when cash represents at least $90 \%$ of the bid. The results are robust to these alternate specifications as well.

\footnotetext{
${ }^{40}$ Similarly, we repeat the tests by excluding Hong Kong - Singapore bids and find that the inferences are unaltered. We also repeat the tests for a smaller sub-sample of only Anglo-American targets (Australia, Canada, New Zealand, the United Kingdom, and the United States) without altering inferences.
} 


\section{Conclusions}

We document that, on average, firms from developing countries (compared to those from developed countries) bid higher to acquire assets in developed countries. Recent anecdotal evidence suggests that one reason for these higher premiums is that they involve high-profile acquisitions accompanied by nationalistic and political considerations (non-economic reasons at first glance). To the extent that national pride sentiments influence individual corporate decision makers, we expect to find a positive relation between national pride and bid premiums.

To address the impact of national pride on bid premiums, we use a novel measure of national pride based on manual examination of media articles surrounding the bids. We find that deals accompanied by national pride considerations on average result in higher premiums. We also construct an indirect (but more easily measurable) measure of national pride - excess media coverage of the bid. Excess media coverage and bid premiums are positively related as well, reinforcing our results using the direct measure of national pride. Our results are robust to a variety of national and firm-level control factors, and to numerous sensitivity analyses.

The analyses in this paper do not allow us to discriminate between rational and irrational explanations about the role of our measure of national pride. It could well be that managers of these firms act perfectly rational. Firms may obtain additional benefits from national governments and the public in general for incurring the cost of higher (successful) bids. In other words, these managers merely display national pride for external audiences, but are rational economic agents. However, using data provided by Faccio (2006a), we find no evidence that our results for national pride are driven by firms that are politically connected. We leave it for future research to further explore the indirect payoffs associated with display of national pride. 


\section{References}

Amihud, Y. and B. Lev. 1981. "Risk Reduction as a Managerial Motive for Conglomerate Mergers.” Bell Journal of Economics Vol. 12: 605-617.

Amihud, Y. and B. Lev. 1999. "Does corporate ownership structure affect its strategy toward diversification?" Strategic Management Journal Vol. 20 No. 11: 1063-1069.

Baker, G. 1986. "Compensation and hierarchies." Working paper, Harvard Business School.

Ball, R., A. Robin and J. Wu. 2003. "Incentives vs. Standards: Properties of Accounting Income in Four East Asian Countries." Journal of Accounting and Economics Vol. 36: 235-270

Baumol, W. 1959. "Business Behavior, Value, and Growth." MacMillan, New York.

Bebchuk, L. and Y. Grinstein. 2005. "Firm expansion and CEO pay." Working paper, Harvard University.

Benartzi, S. and R.H. Thaler. 1995. "Myopic Loss-Aversion and the Equity Premium Puzzle." Quarterly Journal of Economics Vol. 110.1: 73-92.

Bhattacharya, U., N.E. Galpin, R. Rina, and X. Yu. 2008. "The Role of the Media in the Internet IPO Bubble." Forthcoming, Journal of Financial and Quantitative Analysis.

Bottazzi, L., M. Da Rin, and T. Hellman. 2006. "The Importance of Trust for Investment: Evidence from Venture Capital." Working Paper, University of British Columbia.

Bris, A., N. Brisley and C. Cabolis. 2008. "Adopting Better Corporate Governance: Evidence from Cross-border Mergers", Forthcoming, Journal of Corporate Finance.

Bushman, R., J. Piotroski, and A. Smith. 2004. "What Determines Corporate Transparency?" Journal of Accounting Research Vol. 42 No. 2: 207-252.

Chakrabarti, R., N. Jayaraman, and S. Gupta-Mukherjee. 2008. "Mars-Venus Marriages: Culture and Cross-Border M\&A." Forthcoming, Journal of International Business Studies.

Chan, W. 2003. "Stock Price Reaction to News and No-News: Drift and Reversal after Headlines." Journal of Financial Economics Vol. 70: 223-260.

Coval, J., and T. Moskowitz. 1999. "Home bias at home: Local equity preference in domestic portfolios." Journal of Finance Vol. 54: 2045-2073.

Darling, J. and Kraft, F. 1977. "A competitive profile of products and associated marketing practices of selected European and non-European countries." European Journal of Marketing, Vol. 11: 521-42.

Denis, D., D. Denis, and K. Yost. 2002. "Global diversification, industrial diversification, and firm value.” Journal of Finance Vol. 57: 1951-1979.

Diggle, P., K. Liang and S. Zeger. 1994. "Analysis of Longitudinal Data.” Oxford University Press.

Dyck, A., N. Volchkova and L. Zingales. 2008. "Corporate Governance Role of the Media: Evidence from Russia." Forthcoming, Journal of Finance.

Ellemers N, R. Spears, and B. Doosje. 2002. "Self and social identity." Annual Review of Psychology Vol. 53: 161-186.

Ellemers N, R. Spears, and B. Doosje. 1999. Social identity: Context, commitment, content, Oxford: Basil Blackwell.

Faccio, M. 2006a, "Politically connected firms." American Economic Review Vol. 96 No. 1: 369-386.

Faccio, M. 2006b. "The characteristics of politically connected firms." Working paper, Vanderbilt University. 
Faccio, M., J.J. McConnell, and R.W. Masulis. 2006. "Political connections and corporate bailouts." Journal of Finance Vol. 61 No. 6: 2597-2635.

Fan, J.P.H., T.J. Wong, and T. Zhang. 2007. "Politically connected CEOs, corporate governance, and post-IPO performance in China's newly partially privatized firms." Journal of Financial Economics Vol. 84 No. 2: 330-357.

Fisman, R. 2001. "Estimating the value of political connections." American Economic Review Vol. 91 No.4: 1095-1102.

Froot, K. and J. Stein. 1991. "Exchange Rates and Foreign Direct Investment: An Imperfect Capital Markets Approach, Quarterly Journal of Economics 106 (4): 1191-1217.

Gaedeke, R. 1973. "Consumer attitudes toward products 'made in' developing countries." Journal of Retailing Vol. 49 Summer: 13-24.

Gray, S.1988. Towards a theory of cultural influence on the development of accounting systems internationally. Abacus Vol. 24 No. 1: 1-15.

Grinblatt, M., and M. Keloharju. 2008. "Sensation seeking, overconfidence, and trading activity." Forthcoming, Journal of Finance.

Grossman, S., and O. Hart. 1980. "Takeover bids, the free rider problem, and the theory of the corporation." Bell Journal of Economics 11: 42-69.

Guiso, L., P. Sapienza and L. Zingales. 2006. "Does Culture Affect Economic Outcomes?" The Journal of Economic Perspectives Vol. 20: 23-48.

Harris, R. and D. Ravenscraft. 1991. "The Role of Acquisitions in Foreign Direct Investment: Evidence from the U.S. Stock Market." The Journal of Finance 46 (3): 825-844.

Hofstede, G. "Culture's consequences: International differences in work-related values." Beverley Hills: Sage Publications. 1980.

Hope, O.-K. 2003. "Firm-level disclosures and the relative roles of culture and legal origin." Journal of International Financial Management and Accounting Vol. 14 No. 3: 218-248.

Hope, O.-K. and W.B. Thomas. 2008. "Managerial Empire Building and Firm Disclosure." Forthcoming, Journal of Accounting Research.

House, R.J., P.J. Hanges, Javidan, M., P.W. Dorfman, and V. Gupta 2004. Culture, leadership, and organizations: The GLOBE study of 62 societies. Sage Publications, Inc.

Jensen, M.C. 1986. "Agency Cost Of Free Cash Flow, Corporate Finance, and Takeovers." American Economic Review Vol. 76 No. 2: 323-329.

Jensen, M.C. and K. J. Murphy. 1990. "Performance Pay and Top-Management Incentives." Journal of Political Economy Vol. 98 (April): 225-264.

Jiraporn, P. Y.S. Kim, W.N. Davidson, and M. Singh. 2006. "Corporate governance, shareholder rights and firm diversification: An empirical analysis." Journal of Banking and Finance Vol. 30 No. 3: 947-963.

Kahneman, D. and A. Tversky. 1979. "Prospect Theory: An Analysis of Decision under Risk." Econometrica Vol. 46 No. 2: 171-185.

Kwok, C. and D. Reeb. 2000. "Internationalization and Firm Risk: An Upstream-Downstream Hypothesis." Journal of International Business Studies 31: 611-629.

La Porta, R., F. Lopez-De-Silanes, A. Shleifer, and R.W. Vishny. 1997. "Legal determinants of external finance." Journal of Finance Vol. 52: 1131-1150.

La Porta, Rafael, F. Lopez-de-Silanes, A. Shleifer, and R. W. Vishny. 1998. "Law and Finance." The Journal of Political Economy Vol. 106: 1113-1156.

Lerner, J. S. and D. Keltner. 2000. "Beyond valence: Toward a model of emotion-specific influences on judgement and choice." Cognition \& Emotion Vol. 14 No.4: 473 - 493. 
Leuz, C. and F. Oberholzer-Gee. 2006. "Political Relationships, Global Financing, and Corporate Transparency: Evidence from Indonesia." Journal of Financial Economics Vol. 81 No. 2: 411-439.

Loewenstein, G. 2000. "Preferences, Behavior, and Welfare: Emotions in Economic Theory and Economic Behavior." The American Economic Review Vol. 90 No. 2: 426-432.

Lombardo, D., and M. Pagano. 2002. "Law and Equity Markets: A Simple Model." In Corporate governance regimes: Convergence and diversity, edited by Luc Renneboog, Joe McCahery, Pieter Moerland, and Theo Raaijmakers, Oxford University Press: 343-362.

Louro, M.J., R. Pieters, and M. Zeelenberg. 2005. "Negative Returns on Positive Emotions." Journal of Consumer Research Vol. 31: 833-840

Malmendier, U. and G. Tate. 2008. "Who makes Acquisitions? CEO Overconfidence and the Market's Reaction." Forthcoming, Journal of Financial Economics.

Morosini, P., S. Shane, H. Singh. 1998. "National Cultural Distance and Cross-border Acquisition Performance.” Journal of International Business Studies Vol. 29 No.1: 137158.

Mukhopadhyay, A. and G. V. Johar. 2007. "Purchase History and Affective Advertising." Journal of Consumer Research Vol. 33: 445-453.

Müller-Peters, A. 1998. "The significance of national pride and national identity to the attitude toward the single European currency: A Europe-wide comparison." Journal of Economic Psychology Vol. 19: 701-719.

Murphy, K. J. 1985. "Corporate Performance and Managerial Remuneration: An Empirical Analysis." Journal of Accounting and Economics Vol. 7: 11-42.

Odean, T. 1998. “Are Investors Reluctant to Realize Their Losses?” Journal of Finance Vol. 53: $1775-1798$.

Officer, M. 2003. "Termination fees in mergers and acquisitions." Journal of Financial Economics Vol. 69 No. 2: 431-467

Robinson, J, and P. Shane. 1990. "Acquisition Accounting Method and Bid Premia for Target Firms," The Accounting Review Vol. 65 No. 1: 25-48.

Roll, R. 1986. "The Hubris Hypothesis of Corporate Takeovers." Journal of Business Vol. 59, 197-216.

Rose, N.L., and A. Shepard. 1997. "Firm Diversification and CEO Compensation: Managerial Ability or Executive Entrenchment?" RAND Journal of Economics Vol. 28: 489-514.

Rossi, S. and P. Volpin. 2004. "Cross-country determinants of mergers and acquisitions." Journal of Financial Economics Vol. 74: 277-304.

Salter, S. B. and F. Niswander. 1995. "Cultural influence on the development of accounting systems internationally: a test of Gray's (1988) theory." Journal of International Business Studies 2: 379-397.

Shleifer, A. and R. Vishny. 1989. "Management entrenchment - The case of manager - specific investments." Journal of Financial Economics Vol. 25: 123-139.

Scholes, M. and M. Wolfson. 1990. "The Effects of Changes in Tax Laws on Corporate Reorganization Activity." Journal of Business 63: S141-S164.

Schumpeter, J. 1911. "Theorie der Wirtschaftlichen Entwicklung." Leipzig: Dunker \& Humblot. ("The Theory of Economic Development." Cambridge, MA: Harvard University Press, 1934).

Smith, T.W. and S. Kim. 2006. "National pride in comparative perspective: 1995/96 and 2003/04." International Journal of Public Opinion Research Vol. 18 No. 1: 127-136. 
Stulz, R. 1990. "Managerial Discretion and Optimal Financing Policies." Journal of Financial Economics Vol. 26 No. 1: 3-27.

Stulz, R. and R. Williamson. 2003. "Culture, openness, and finance.” Journal of Financial Economics Vol. 70: 313-349.

Tajfel, H. and J. Turner, 1979. "An integrative theory of intergroup conflict.” In Social Psychology of Intergroup Relations (pp. 33-47). Belmont, CA: Wadsworth.

Thaler, R.H. 1992. The Winner's Curse: Paradoxes and Anomalies of Economic Life. New York: The Free Press.

Walkling R. and O. Edmister. 1985. "Determinants of Tender Offer Premiums." Financial Analysts Journal Vol. 41: 27-37.

Wall, M. and Heslop, L. 1986. "Consumer attitudes toward Canadian-made vs. imported products", Journal of the Academy of Marketing Science Vol. 14 Summer: 27-36.

Williamson, O. 1974. Economics of Discretionary Behaviour: Managerial Objectives in a Theory of the Firm. Kershaw Publishing, London.

Zhang, Y. 1996. 'Chinese consumers' evaluation of foreign product: the influence of culture, product types and product presentation format." European Journal of Marketing Vol. 30 No. 12: 50-68. 
Table 1: Distribution of bids from developing countries for firms in developed countries.

\section{Panel A: Full sample of bids}

\section{Targets}

Hong Hun- Luxem- New Nor- Por- United United

\begin{tabular}{|c|c|c|c|c|c|c|c|c|c|c|c|c|c|c|c|c|c|c|}
\hline \multirow{2}{*}{\multicolumn{19}{|c|}{ Australia Bahamas Belgium muda Canada France }} \\
\hline & & & & & & & & & & & & & & & & & & \\
\hline Argentina & 0 & 0 & 0 & 0 & 0 & 0 & 0 & 0 & 0 & 0 & 0 & 0 & 0 & 0 & 0 & 6 & 0 & 6 \\
\hline Bahrain & 0 & 0 & 0 & 0 & 0 & 0 & 0 & 0 & 0 & 0 & 0 & 0 & 0 & 0 & 0 & 3 & 0 & 3 \\
\hline Brazil & 0 & 0 & 0 & 0 & 3 & 0 & 0 & 0 & 0 & 0 & 0 & 0 & 0 & 0 & 1 & 0 & 0 & 4 \\
\hline China & 1 & 0 & 0 & 0 & 0 & 0 & 0 & 32 & 0 & 0 & 0 & 1 & 0 & 0 & 2 & 4 & 0 & 40 \\
\hline Cyprus & 1 & 0 & 0 & 0 & 0 & 0 & 2 & 0 & 1 & 0 & 0 & 0 & 1 & 0 & 0 & 0 & 0 & 5 \\
\hline Egypt & 0 & 0 & 0 & 0 & 0 & 0 & 0 & 1 & 0 & 0 & 0 & 0 & 0 & 0 & 0 & 0 & 0 & 1 \\
\hline Ghana & 1 & 0 & 0 & 0 & 1 & 0 & 0 & 0 & 0 & 0 & 0 & 0 & 0 & 0 & 2 & 0 & 0 & 4 \\
\hline India & 1 & 0 & 2 & 2 & 1 & 0 & 0 & 0 & 0 & 0 & 1 & 0 & 2 & 0 & 2 & 3 & 0 & 14 \\
\hline Indonesia & 3 & 0 & 0 & 0 & 0 & 0 & 0 & 1 & 0 & 0 & 0 & 0 & 0 & 0 & 1 & 0 & 0 & 5 \\
\hline Kuwait & 0 & 0 & 0 & 0 & 0 & 0 & 0 & 0 & 0 & 0 & 0 & 0 & 0 & 0 & 1 & 4 & 0 & 5 \\
\hline Liberia & 0 & 0 & 0 & 0 & 0 & 0 & 1 & 0 & 0 & 0 & 0 & 0 & 0 & 0 & 0 & 0 & 0 & 1 \\
\hline Lithuania & 0 & 0 & 0 & 0 & 0 & 0 & 0 & 0 & 0 & 0 & 0 & 0 & 0 & 0 & 0 & 0 & 1 & 1 \\
\hline Macau & 0 & 0 & 0 & 0 & 0 & 0 & 0 & 1 & 0 & 0 & 0 & 0 & 0 & 0 & 0 & 0 & 0 & 1 \\
\hline Malawi & 0 & 0 & 0 & 0 & 0 & 0 & 0 & 0 & 0 & 0 & 0 & 0 & 0 & 1 & 0 & 0 & 0 & 1 \\
\hline Malaysia & 13 & 0 & 0 & 0 & 1 & 0 & 0 & 6 & 0 & 0 & 0 & 1 & 2 & 0 & 1 & 7 & 0 & 31 \\
\hline Mexico & 1 & 0 & 0 & 0 & 0 & 0 & 0 & 0 & 0 & 1 & 0 & 0 & 0 & 0 & 0 & 9 & 1 & 12 \\
\hline Morocco & 0 & 0 & 0 & 0 & 0 & 1 & 0 & 0 & 0 & 0 & 0 & 0 & 0 & 0 & 0 & 0 & 0 & 1 \\
\hline Papua N Guinea & 2 & 0 & 0 & 0 & 0 & 0 & 0 & 0 & 0 & 0 & 0 & 0 & 0 & 0 & 0 & 0 & 0 & 2 \\
\hline Peru & 0 & 0 & 0 & 0 & 1 & 0 & 0 & 0 & 0 & 0 & 0 & 0 & 0 & 0 & 0 & 0 & 0 & 1 \\
\hline Philippines & 2 & 0 & 0 & 0 & 0 & 0 & 0 & 2 & 0 & 0 & 0 & 0 & 0 & 0 & 1 & 0 & 0 & 5 \\
\hline Russian Fed & 0 & 0 & 0 & 0 & 0 & 0 & 0 & 0 & 0 & 0 & 0 & 0 & 0 & 0 & 0 & 5 & 0 & 5 \\
\hline Saudi Arabia & 0 & 0 & 0 & 0 & 1 & 0 & 0 & 0 & 0 & 0 & 0 & 0 & 0 & 0 & 1 & 4 & 0 & 6 \\
\hline Singapore & 10 & 0 & 0 & 0 & 0 & 0 & 0 & 21 & 1 & 4 & 0 & 6 & 0 & 0 & 4 & 19 & 1 & 66 \\
\hline South Africa & 29 & 0 & 0 & 0 & 1 & 0 & 0 & 0 & 0 & 0 & 1 & 0 & 0 & 0 & 7 & 4 & 1 & 43 \\
\hline South Korea & 0 & 0 & 0 & 0 & 0 & 0 & 0 & 1 & 0 & 0 & 0 & 0 & 0 & 0 & 0 & 11 & 0 & 12 \\
\hline Sri Lanka & 0 & 0 & 0 & 0 & 0 & 0 & 0 & 1 & 0 & 0 & 0 & 0 & 0 & 0 & 0 & 0 & 0 & 1 \\
\hline Thailand & 1 & 0 & 0 & 0 & 0 & 0 & 0 & 0 & 0 & 1 & 0 & 0 & 0 & 1 & 0 & 2 & 0 & 5 \\
\hline Trinidad\&Tob & 0 & 0 & 0 & 0 & 0 & 1 & 0 & 0 & 0 & 0 & 0 & 0 & 0 & 0 & 0 & 0 & 0 & 1 \\
\hline Turkey & 0 & 0 & 0 & 0 & 0 & 0 & 0 & 0 & 0 & 0 & 0 & 0 & 0 & 0 & 0 & 2 & 0 & 2 \\
\hline Utd Arab Em & 1 & 2 & 0 & 0 & 2 & 0 & 1 & 0 & 0 & 0 & 0 & 0 & 0 & 0 & 2 & 0 & 1 & 9 \\
\hline Venezuela & 0 & 0 & 0 & 0 & 0 & 0 & 0 & 0 & 0 & 0 & 0 & 0 & 0 & 0 & 0 & 2 & 0 & 2 \\
\hline Total & 66 & 2 & 2 & 2 & 11 & 2 & 4 & 66 & 2 & 6 & 2 & 8 & 5 & 2 & 25 & 85 & 5 & 295 \\
\hline
\end{tabular}


Table 1 (continued): Distribution of bids from developing countries for firms in developed countries.

\begin{tabular}{|c|c|c|c|c|c|c|c|c|}
\hline \\
\hline \multicolumn{9}{|c|}{ Panel B: Identified as national pride bids } \\
\hline & Australia & Belgium & Canada & $\begin{array}{l}\text { Hong } \\
\text { Kong }\end{array}$ & $\begin{array}{l}\text { Luxem- } \\
\text { bourg }\end{array}$ & $\begin{array}{r}\text { United } \\
\text { Kingdom }\end{array}$ & $\begin{array}{r}\text { United } \\
\text { States }\end{array}$ & Total \\
\hline \multicolumn{9}{|l|}{ Bidders } \\
\hline Brazil & 0 & 0 & 1 & 0 & 0 & 1 & 0 & 2 \\
\hline China & 0 & 0 & 0 & 0 & 0 & 1 & 1 & 2 \\
\hline India & 0 & 2 & 0 & 0 & 1 & 1 & 1 & 5 \\
\hline Malaysia & 1 & 0 & 0 & 2 & 0 & 0 & 2 & 5 \\
\hline Mexico & 1 & 0 & 0 & 0 & 0 & 0 & 1 & 2 \\
\hline Philippines & 1 & 0 & 0 & 0 & 0 & 0 & 0 & 1 \\
\hline Russia & 0 & 0 & 0 & 0 & 0 & 0 & 1 & 1 \\
\hline Saudi Arabia & 0 & 0 & 0 & 0 & 0 & 0 & 1 & 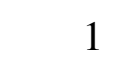 \\
\hline Singapore & 0 & 0 & 0 & 0 & 0 & 0 & 1 & 1 \\
\hline South Africa & 6 & 0 & 0 & 0 & 1 & 0 & 0 & 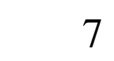 \\
\hline South Korea & 0 & 0 & 0 & 0 & 0 & 0 & 7 & 7 \\
\hline Turkey & 0 & 0 & 0 & 0 & 0 & 0 & 2 & 2 \\
\hline Total & 9 & 2 & 1 & 2 & 2 & 3 & 17 & 36 \\
\hline
\end{tabular}


Table 2: Description of variables.

\begin{tabular}{|c|c|c|}
\hline Variable & Source & Description \\
\hline \multicolumn{3}{|l|}{ Deal characteristics } \\
\hline Premium & SDC Platinum & $\begin{array}{l}\text { Defined as: (bid price per share - target } \\
\text { closing stock price four weeks prior to } \\
\text { announcement)/(target closing stock price } \\
\text { four weeks prior to announcement)*100 }\end{array}$ \\
\hline$\%$ Sought & SDC Platinum & $\begin{array}{l}\text { Percentage of outstanding shares sought } \\
\text { by the acquirer. }\end{array}$ \\
\hline Competing bid & SDC Platinum & $\begin{array}{l}\text { Indicator variable which takes on a value } \\
\text { of one if the bid is accompanied by } \\
\text { multiple rival bids. }\end{array}$ \\
\hline Tender offer & SDC Platinum & $\begin{array}{l}\text { Indicator variable that takes on a value of } \\
\text { one if the bid is a tender offer. }\end{array}$ \\
\hline Financial buyer & SDC Platinum & $\begin{array}{l}\text { Indicator variable that takes on a value of } \\
\text { one if the acquirer is a financial } \\
\text { institution. }\end{array}$ \\
\hline Hostile bid & SDC Platinum & $\begin{array}{l}\text { Indicator variable that takes on a value of } \\
\text { one if the bid is hostile or unfriendly. }\end{array}$ \\
\hline Cash bid & SDC Platinum & $\begin{array}{l}\text { Indicator variable that takes on a value of } \\
\text { one if the bid is a cash bid (cash }>90 \%) \text {. }\end{array}$ \\
\hline Successful bid & SDC Platinum & $\begin{array}{l}\text { Indicator variable that takes on a value of } \\
\text { one if the deal has been completed. }\end{array}$ \\
\hline Media coverage & Factiva & $\begin{array}{l}\text { Article count obtained on Factiva using } \\
\text { the target's and the bidder's names in the } \\
\text { search string during the time period three } \\
\text { months prior to the date of announcement } \\
\text { to the date of announcement. }\end{array}$ \\
\hline $\begin{array}{l}\text { Newsworthiness of target } \\
\text { (bidder) }\end{array}$ & Factiva & $\begin{array}{l}\text { Calculated as article count obtained on } \\
\text { Factiva using the target's (bidder's) name } \\
\text { in the search string during the time period } \\
24 \text { months to } 12 \text { months prior to } \\
\text { announcement date, divided by four. }\end{array}$ \\
\hline Excess media coverage & Factiva & $\begin{array}{l}\text { Residual from a regression of logarithm of } \\
\text { media coverage on the logarithms of the } \\
\text { newsworthiness of the target and the } \\
\text { bidder. }\end{array}$ \\
\hline
\end{tabular}


Table 2 (continued): Description of variables.

\begin{tabular}{|c|c|c|}
\hline National pride & $\begin{array}{l}\text { Manual Search } \\
\text { on Factiva }\end{array}$ & $\begin{array}{l}\text { Indicator variable that equals one if the } \\
\text { media coverage surrounding the } \\
\text { transaction contains references to national } \\
\text { pride or hubris or political considerations } \\
\text { in the context of the transaction, zero } \\
\text { otherwise. Media articles are examined on } \\
\text { Factiva using target's and the bidder's } \\
\text { names in the search string during the time } \\
\text { period three months prior to the date of } \\
\text { announcement to three months after. }\end{array}$ \\
\hline Cultural distance & $\begin{array}{l}\text { Prof. Geert } \\
\text { Hofstede's } \\
\text { website }\end{array}$ & $\begin{array}{l}\text { Square root of the sum of squared } \\
\text { differences on Hofstede's four dimensions } \\
\text { (Power Distance, Individualism, } \\
\text { Masculinity, and Uncertainty Avoidance) } \\
\text { divided by four. }\end{array}$ \\
\hline Developing country & $\begin{array}{l}\text { United Nations } \\
\text { Statistical } \\
\text { Division }\end{array}$ & $\begin{array}{l}\text { Indicator variable that equals one if the } \\
\text { bidder's parent company is headquartered } \\
\text { in a developing country, zero otherwise. }\end{array}$ \\
\hline
\end{tabular}

\section{Target Characteristics}

Sales

SDC Platinum

Net Sales

Net income

SDC Platinum

Net Income after tax

Net assets

SDC Platinum

Total Assets - Total Liabilities

Profit margin

SDC Platinum

Net Income / Sales

$\log$ (GDP per capita)

International

Financial

Statistics, IMF

Logarithm of nominal GDP per capita, averaged over 1990 to 2006.

Shareholder protection

Prof. Andrei

Following Rossi and Volpin (2004):

Shleifer's

website

"Anti-director rights" multiplied by "Rule of Law" divided by 10. Anti-director Rights and "Rule of Law" as defined in La Porta et al. 1998.

Cultural distance (Hofstede's Prof. Geert measures)

Hofstede's

website

Based on Hofstede's four primary dimensions to assist in differentiating cultures: Power Distance, Individualism, Masculinity, and Uncertainty Avoidance. 
Table 3: Descriptive statistics.

\section{Panel A: Full sample}

\begin{tabular}{lrrrrr} 
Variable $^{\mathrm{a}}$ & M of obs. & Mean & Std. Dev. & $\begin{array}{c}25 \\
\text { percentile }\end{array}$ & $\begin{array}{c}75 \\
\text { percentile }\end{array}$ \\
\hline Deal characteristics & & & & & \\
Log(Premium) & & & & & \\
Developing country & 3,806 & 3.23 & 1.18 & 2.65 & 3.99 \\
\%Sought & 3,806 & 0.08 & 0.27 & 0.00 & 0.00 \\
Competing bid & 3,806 & 61.83 & 39.58 & 19.60 & 100.00 \\
Successful bid & 3,806 & 0.08 & 0.27 & 0.00 & 0.00 \\
Tender offer & 3,806 & 0.78 & 0.42 & 1.00 & 1.00 \\
Financial buyer & 3,806 & 0.45 & 0.50 & 0.00 & 1.00 \\
Hostile bid & 3,806 & 0.11 & 0.31 & 0.00 & 0.00 \\
Cash bid & 3,806 & 0.05 & 0.23 & 0.00 & 0.00 \\
Cultural distance & 3,806 & 0.58 & 0.49 & 0.00 & 1.00 \\
& 3,548 & 7.28 & 6.87 & 0.00 & 13.80 \\
Target characteristics & & & & & \\
Profit margin & 3,806 & -6.97 & $2,236.65$ & -0.01 & 0.09 \\
Log(Net assets) & 3,806 & 4.59 & 1.89 & 3.38 & 5.80 \\
Shareholder protection & 3,690 & 3.98 & 1.19 & 3.59 & 5.00 \\
Log(GDP per capita) & 3,766 & 10.14 & 0.32 & 10.04 & 10.34 \\
& & & & & \\
\hline
\end{tabular}

${ }^{a}$ Variables are defined in Table 2. 
Table 3 (continued): Descriptive statistics.

Panel B: Bids from developing countries for targets in developed countries

\begin{tabular}{|c|c|c|c|c|c|}
\hline Variable $^{\mathrm{a}}$ & \# of obs. & Mean & Std. Dev. & $\begin{array}{c}25^{\text {th }} \\
\text { percentile }\end{array}$ & $\begin{array}{c}75^{\text {th }} \\
\text { percentile }\end{array}$ \\
\hline \multicolumn{6}{|l|}{ Deal Characteristics } \\
\hline Log(Premium) & 295 & 3.22 & 1.23 & 2.48 & 3.96 \\
\hline National pride & 295 & 0.12 & 0.32 & 0.00 & 0.00 \\
\hline$\%$ Sought & 295 & 43.20 & 38.04 & 9.70 & 90.00 \\
\hline Competing bid & 295 & 0.08 & 0.28 & 0.00 & 0.00 \\
\hline Successful bid & 295 & 0.78 & 0.42 & 1.00 & 1.00 \\
\hline Tender offer & 295 & 0.27 & 0.45 & 0.00 & 1.00 \\
\hline Financial buyer & 295 & 0.10 & 0.30 & 0.00 & 0.00 \\
\hline Hostile bid & 295 & 0.03 & 0.18 & 0.00 & 0.00 \\
\hline Cash bid & 295 & 0.56 & 0.50 & 0.00 & 1.00 \\
\hline Cultural distance & 273 & 59.71 & 30.18 & 28.32 & 88.53 \\
\hline \multicolumn{6}{|l|}{ Target Characteristics } \\
\hline Profit margin & 295 & -37.70 & 496.88 & -0.03 & 0.10 \\
\hline Log(Net assets) & 295 & 4.38 & 1.88 & 2.92 & 5.57 \\
\hline Shareholder Protection & 285 & 4.28 & 0.74 & 4.00 & 5.00 \\
\hline
\end{tabular}

${ }^{\text {a }}$ Variables are defined in table 2. 
Table 3 (continued): Descriptive statistics.

\begin{tabular}{|c|c|c|c|c|c|c|c|c|c|c|}
\hline \multicolumn{11}{|c|}{ Panel C: Pearson correlations } \\
\hline & $\begin{array}{l}\text { National } \\
\text { Pride }\end{array}$ & $\begin{array}{c}\log (\mathrm{Net} \\
\text { Assets) }\end{array}$ & $\begin{array}{c}\text { Financial } \\
\text { Buyer }\end{array}$ & $\begin{array}{l}\text { Profit } \\
\text { Margin }\end{array}$ & $\begin{array}{l}\text { Tender } \\
\text { Offer }\end{array}$ & $\begin{array}{l}\text { Successful } \\
\text { Bid }\end{array}$ & $\begin{array}{l}\text { Competing } \\
\text { Bid }\end{array}$ & $\begin{array}{c}\% \\
\text { Sought }\end{array}$ & $\begin{array}{l}\text { Cash } \\
\text { Bid }\end{array}$ & Hostile Bid \\
\hline \multirow{2}{*}{$\begin{array}{l}\log (\text { Pre- } \\
\text { mium })\end{array}$} & 0.209 & -0.099 & -0.077 & 0.031 & 0.184 & -0.045 & 0.156 & 0.278 & 0.078 & 0.072 \\
\hline & 0.000 & 0.089 & 0.189 & 0.595 & 0.002 & 0.440 & 0.007 & $<.0001$ & 0.184 & 0.216 \\
\hline National & & 0.267 & -0.054 & 0.028 & 0.127 & -0.080 & 0.189 & 0.208 & -0.012 & 0.279 \\
\hline Pride & & $<.0001$ & 0.355 & 0.633 & 0.030 & 0.172 & 0.001 & 0.000 & 0.835 & $<.0001$ \\
\hline $\log (\mathrm{Net}$ & & & -0.010 & 0.136 & 0.057 & 0.174 & 0.272 & 0.105 & 0.072 & 0.050 \\
\hline Assets) & & & 0.862 & 0.020 & 0.328 & 0.003 & $<.0001$ & 0.071 & 0.221 & 0.395 \\
\hline Financial & & & & -0.042 & -0.031 & -0.035 & -0.022 & -0.018 & 0.005 & -0.063 \\
\hline Buyer & & & & 0.470 & 0.595 & 0.553 & 0.709 & 0.754 & 0.932 & 0.281 \\
\hline Profit & & & & & 0.047 & 0.009 & 0.023 & 0.062 & 0.086 & 0.014 \\
\hline Margin & & & & & 0.425 & 0.877 & 0.692 & 0.288 & 0.142 & 0.808 \\
\hline Tender & & & & & & 0.166 & 0.276 & 0.514 & 0.194 & 0.179 \\
\hline Offer & & & & & & $<.0001$ & $<.0001$ & $<.0001$ & 0.001 & 0.002 \\
\hline Successful & & & & & & & -0.129 & -0.034 & 0.130 & -0.169 \\
\hline Bid & & & & & & & 0.027 & 0.566 & 0.026 & 0.004 \\
\hline Competing & & & & & & & & 0.380 & 0.123 & 0.078 \\
\hline Bid & & & & & & & & 0.035 & 0.035 & 0.184 \\
\hline$\%$ & & & & & & & & & 0.087 & 0.214 \\
\hline Sought & & & & & & & & & 0.135 & 0.000 \\
\hline Cash & & & & & & & & & & -0.022 \\
\hline $\mathrm{Bid}$ & & & & & & & & & & 0.702 \\
\hline
\end{tabular}

Variables are defined in Table 2. The sample consists of firms in developing countries bidding for firms in developed countries $(\mathrm{N}=295)$. Figures in italics represent two-sided p-values. 
Table 4: Effect of Developing Country Bidders on Bid Premium

\begin{tabular}{|c|c|c|c|}
\hline \multicolumn{4}{|c|}{$\begin{array}{l}\text { Panel A: Targets in developed countries } \\
\qquad \log (\text { Premium })=a+b^{*}(\text { Developing country })+c^{*}(\text { Control variables })\end{array}$} \\
\hline Variables $^{\mathrm{a}}$ & I. & II. & III. \\
\hline Intercept & $\begin{array}{c}2.918 * * * \\
{[0.379]}\end{array}$ & $\begin{array}{c}2.893 * * * \\
{[0.383]}\end{array}$ & $\begin{array}{c}2.891 * * * \\
{[0.387]}\end{array}$ \\
\hline Developing country & $\begin{array}{l}0.149 * \\
{[0.081]}\end{array}$ & $\begin{array}{l}\mathbf{0 . 1 5 7 *} \\
{[\mathbf{0 . 0 8 1}]}\end{array}$ & $\begin{array}{l}0.155 * \\
{[0.094]}\end{array}$ \\
\hline Target shareholder protection & & $\begin{array}{l}0.039 * * \\
{[0.019]}\end{array}$ & $\begin{array}{l}0.036^{*} \\
{[0.019]}\end{array}$ \\
\hline Cultural distance & & & $\begin{array}{c}0.004 \\
{[0.003]}\end{array}$ \\
\hline $\log ($ Net assets $)$ & $\begin{array}{c}-0.069 * * * \\
{[0.012]}\end{array}$ & $\begin{array}{c}-0.068 * * * \\
{[0.012]}\end{array}$ & $\begin{array}{c}-0.069 * * * \\
{[0.012]}\end{array}$ \\
\hline Profit margin & $\begin{array}{c}0.007 * * \\
{[0.003]}\end{array}$ & $\begin{array}{c}0.007 * \\
{[0.004]}\end{array}$ & $\begin{array}{c}0.009 * * \\
{[0.004]}\end{array}$ \\
\hline$\%$ Sought & $\begin{array}{c}0.009 * * * \\
{[0.001]}\end{array}$ & $\begin{array}{c}0.009 * * * \\
{[0.001]}\end{array}$ & $\begin{array}{c}0.009 * * * \\
{[0.001]}\end{array}$ \\
\hline Competing bid & $\begin{array}{c}0.304 * * * \\
{[0.062]}\end{array}$ & $\begin{array}{c}0.277 * * * \\
{[0.060]}\end{array}$ & $\begin{array}{c}0.287 * * * \\
{[0.062]}\end{array}$ \\
\hline Successful bid & $\begin{array}{c}0.062 \\
{[0.052]}\end{array}$ & $\begin{array}{c}0.053 \\
{[0.052]}\end{array}$ & $\begin{array}{c}0.047 \\
{[0.052]}\end{array}$ \\
\hline Tender offer & $\begin{array}{c}0.067 \\
{[0.041]}\end{array}$ & $\begin{array}{c}0.073 * \\
{[0.039]}\end{array}$ & $\begin{array}{c}0.075^{*} \\
{[0.040]}\end{array}$ \\
\hline Financial buyer & $\begin{array}{c}-0.200 * * * \\
{[0.068]}\end{array}$ & $\begin{array}{c}-0.177 * * \\
{[0.069]}\end{array}$ & $\begin{array}{c}-0.174 * * \\
{[0.070]}\end{array}$ \\
\hline Hostile bid & $\begin{array}{c}0.028 \\
{[0.066]}\end{array}$ & $\begin{array}{c}-0.001 \\
{[0.066]}\end{array}$ & $\begin{array}{c}-0.008 \\
{[0.066]}\end{array}$ \\
\hline Cash bid & $\begin{array}{c}0.029 \\
{[0.039]}\end{array}$ & $\begin{array}{c}0.038 \\
{[0.039]}\end{array}$ & $\begin{array}{c}0.021 \\
{[0.039]}\end{array}$ \\
\hline Year controls & YES & YES & YES \\
\hline Target industry fixed effects & YES & YES & YES \\
\hline Target nation fixed effects & YES & NO & NO \\
\hline \# of observations & 3,806 & 3,690 & 3,548 \\
\hline Adj. $\mathrm{R}^{2}$ & 0.19 & 0.18 & 0.19 \\
\hline
\end{tabular}

${ }^{a}$ Variables are defined in Table 2. Numbers in brackets are Huber-White standard errors adjusted for clustering at the firm (bidder) level.

$*, * *, * * *$ represent significance at the $0.10,0.05$, and 0.01 levels (two-sided tests). 
Table 4 (continued): Effect of Developing Country Bidders on Bid Premium.

Panel B: Target in developing countries

$$
\log (\text { Premium })=a+b *(\text { Developing country })+c *(\text { Control variables })
$$

\begin{tabular}{|c|c|c|c|}
\hline Variables $^{\mathrm{a}}$ & I. & II. & III. \\
\hline \multirow[t]{2}{*}{ Intercept } & $4.849 * * *$ & $3.756^{* * *}$ & $4.099 * * *$ \\
\hline & {$[1.048]$} & {$[0.881]$} & [1.017] \\
\hline \multirow[t]{2}{*}{ Developing country } & -0.031 & -0.015 & -0.13 \\
\hline & {$[0.122]$} & {$[0.118]$} & {$[0.167]$} \\
\hline \multirow[t]{2}{*}{ Target shareholder protection } & & -0.035 & -0.07 \\
\hline & & [0.069] & {$[0.071]$} \\
\hline \multirow[t]{2}{*}{ Cultural distance } & & & -0.016 \\
\hline & & & [0.010] \\
\hline \multirow[t]{2}{*}{$\log ($ Net assets $)$} & -0.061 & -0.05 & -0.06 \\
\hline & [0.038] & [0.036] & [0.037] \\
\hline \multirow[t]{2}{*}{ Profit margin } & $-2.436 * *$ & $-1.840 *$ & $-2.190 * *$ \\
\hline & {$[1.210]$} & [1.015] & [1.072] \\
\hline \multirow[t]{2}{*}{$\%$ Sought } & $0.009 * * *$ & $0.007 * * *$ & $0.007 * * *$ \\
\hline & {$[0.002]$} & {$[0.002]$} & [0.002] \\
\hline \multirow[t]{2}{*}{ Competing bid } & 0.045 & -0.271 & -0.438 \\
\hline & {$[0.732]$} & {$[0.715]$} & [0.822] \\
\hline \multirow[t]{2}{*}{ Successful bid } & 0.078 & 0.1 & 0.148 \\
\hline & {$[0.126]$} & [0.127] & {$[0.138]$} \\
\hline \multirow[t]{2}{*}{ Tender offer } & -0.115 & -0.093 & -0.147 \\
\hline & {$[0.125]$} & [0.126] & [0.133] \\
\hline \multirow[t]{2}{*}{ Financial buyer } & -0.216 & -0.142 & -0.202 \\
\hline & {$[0.175]$} & [0.179] & [0.191] \\
\hline \multirow[t]{2}{*}{ Hostile bid } & $1.214 * *$ & 0.539 & 0.527 \\
\hline & {$[0.611]$} & {$[0.592]$} & [0.641] \\
\hline \multirow[t]{2}{*}{ Cash bid } & 0.082 & 0.029 & 0.002 \\
\hline & {$[0.121]$} & [0.122] & {$[0.135]$} \\
\hline Year controls & YES & YES & YES \\
\hline Industry fixed effects & YES & YES & YES \\
\hline Target nation fixed effects & YES & NO & NO \\
\hline \# of observations & 663 & 635 & 590 \\
\hline Adj. $R^{2}$ & 0.11 & 0.05 & 0.06 \\
\hline
\end{tabular}

${ }^{a}$ Variables are defined in Table 2. Numbers in brackets are Huber-White standard errors adjusted for clustering at the firm (bidder) level.

$*, * *, * * *$ represent significance at the $0.10,0.05$, and 0.01 levels (two-sided tests). 


\begin{tabular}{|c|c|c|c|}
\hline \multicolumn{4}{|c|}{$\log ($ Premium $)=a+b *($ National pride $)+c *($ Control variables $)$} \\
\hline Variables $^{\mathrm{a}}$ & I. & II. & III. \\
\hline \multirow[t]{2}{*}{ Intercept } & $4.792 * * *$ & $4.260 * * *$ & $4.266 * * *$ \\
\hline & [0.869] & [1.035] & [1.011] \\
\hline \multirow[t]{2}{*}{ National pride } & $0.656 * * *$ & $0.673 * * *$ & $0.668 * * *$ \\
\hline & {$[0.234]$} & {$[0.228]$} & {$[0.233]$} \\
\hline \multirow[t]{2}{*}{ Target shareholder protection } & & $0.209 *$ & 0.157 \\
\hline & & [0.118] & {$[0.138]$} \\
\hline \multirow[t]{2}{*}{ Cultural distance } & & & 0.002 \\
\hline & & & [0.003] \\
\hline \multirow[t]{2}{*}{$\log ($ Net assets $)$} & $-0.147 * * *$ & $-0.118 * *$ & $-0.124 * *$ \\
\hline & {$[0.053]$} & {$[0.053]$} & {$[0.054]$} \\
\hline \multirow[t]{2}{*}{ Profit margin } & -0.051 & -0.086 & -0.069 \\
\hline & [0.135] & [0.130] & {$[0.132]$} \\
\hline \multirow[t]{2}{*}{$\%$ Sought } & $0.007 * *$ & $0.006^{* *}$ & $0.006^{*}$ \\
\hline & [0.003] & {$[0.003]$} & {$[0.003]$} \\
\hline \multirow[t]{2}{*}{ Competing bid } & 0.472 & $0.465^{*}$ & $0.489 *$ \\
\hline & {$[0.298]$} & {$[0.277]$} & {$[0.295]$} \\
\hline \multirow[t]{2}{*}{ Successful bid } & -0.219 & -0.214 & -0.226 \\
\hline & {$[0.236]$} & {$[0.235]$} & {$[0.247]$} \\
\hline \multirow[t]{2}{*}{ Tender offer } & -0.051 & 0.086 & 0.062 \\
\hline & [0.234] & {$[0.225]$} & {$[0.234]$} \\
\hline \multirow[t]{2}{*}{ Financial buyer } & -0.289 & -0.27 & -0.365 \\
\hline & {$[0.245]$} & {$[0.228]$} & {$[0.248]$} \\
\hline \multirow[t]{2}{*}{ Hostile bid } & -0.234 & -0.204 & -0.138 \\
\hline & {$[0.342]$} & {$[0.320]$} & {$[0.314]$} \\
\hline \multirow[t]{2}{*}{ Cash bid } & 0.052 & 0.075 & 0.038 \\
\hline & {$[0.164]$} & [0.164] & {$[0.175]$} \\
\hline Year controls & YES & YES & YES \\
\hline Industry fixed effects & YES & YES & YES \\
\hline Target nation fixed effects & YES & NO & NO \\
\hline \# of observations & 295 & 285 & 273 \\
\hline Adjusted $\mathrm{R}^{2}$ & 0.28 & 0.20 & 0.18 \\
\hline
\end{tabular}

${ }^{a}$ Variables are defined in Table 2. Numbers in brackets are Huber-White standard errors adjusted for clustering at the firm (bidder) level.

$*, * *, * * *$ represent significance at the $0.10,0.05$, and 0.01 levels (two-sided tests). 
Table 6: Effect of National Pride on Bid Premiums by Firms from Developing Countries (Alternate Measures)

\begin{tabular}{|c|c|c|c|}
\hline \multicolumn{4}{|c|}{$\log ($ Premium $)=a+b *$ Measures of pride $+c *($ Control variables $)$} \\
\hline Variables $^{\mathrm{a}}$ & I. & II. & III. \\
\hline \multirow[t]{2}{*}{ Intercept } & $4.712 * * *$ & $4.603 * * *$ & $4.687 * * *$ \\
\hline & {$[0.904]$} & [0.903] & {$[0.887]$} \\
\hline \multirow[t]{2}{*}{ Log(Media coverage $)$} & $0.042 * *$ & & \\
\hline & {$[0.021]$} & & \\
\hline \multirow[t]{2}{*}{ Excess media coverage } & & $0.041 *$ & $\mathbf{0 . 0 3 8}$ \\
\hline & & {$[0.024]$} & {$[0.024]$} \\
\hline \multirow[t]{2}{*}{ National pride } & & & $0.631 * * *$ \\
\hline & & & {$[0.237]$} \\
\hline \multirow[t]{2}{*}{$\log ($ Net assets $)$} & $-0.139 * * *$ & $-0.124 * *$ & $-0.144 * * *$ \\
\hline & [0.052] & {$[0.053]$} & [0.053] \\
\hline \multirow[t]{2}{*}{ Profit margin } & -0.043 & -0.054 & -0.051 \\
\hline & {$[0.134]$} & [0.134] & {$[0.135]$} \\
\hline \multirow[t]{2}{*}{$\%$ Sought } & $0.007 *$ & $0.007 * *$ & $0.007 * *$ \\
\hline & {$[0.003]$} & {$[0.003]$} & {$[0.003]$} \\
\hline \multirow[t]{2}{*}{ Competing bid } & $0.606^{* *}$ & $0.625 * *$ & $0.548 *$ \\
\hline & {$[0.285]$} & {$[0.281]$} & {$[0.293]$} \\
\hline \multirow[t]{2}{*}{ Successful bid } & -0.301 & -0.27 & -0.21 \\
\hline & [0.233] & {$[0.235]$} & {$[0.233]$} \\
\hline \multirow[t]{2}{*}{ Tender offer } & -0.038 & -0.053 & -0.084 \\
\hline & {$[0.236]$} & {$[0.230]$} & {$[0.232]$} \\
\hline \multirow[t]{2}{*}{ Financial buyer } & -0.191 & -0.219 & -0.215 \\
\hline & {$[0.240]$} & [0.239] & [0.237] \\
\hline \multirow[t]{2}{*}{ Hostile bid } & 0.017 & 0.021 & -0.254 \\
\hline & {$[0.307]$} & [0.305] & {$[0.335]$} \\
\hline \multirow[t]{2}{*}{ Cash bid } & 0.064 & 0.049 & 0.04 \\
\hline & {$[0.162]$} & {$[0.163]$} & {$[0.160]$} \\
\hline Year controls & YES & YES & YES \\
\hline Industry fixed effects & YES & YES & YES \\
\hline Target nation fixed effects & YES & YES & YES \\
\hline \# of observations & 295 & 295 & 295 \\
\hline Adjusted $\mathrm{R}^{2}$ & 0.27 & 0.27 & 0.29 \\
\hline
\end{tabular}

${ }^{a}$ Variables are defined in Table 2. Numbers in brackets are Huber-White standard errors adjusted for clustering at the firm (bidder) level.

$*, * *, * * *$ represent significance at the $0.10,0.05$, and 0.01 levels (two-sided tests). 